\title{
Atmospheric Dioxin and Furan Deposition in Relation to Land-Use and Other Pollutants: A Survey with Lichens
}

\author{
S. AUGUSTO ${ }^{1}$, P. PINHO ${ }^{2}$, C. BRANQUINHO ${ }^{3}$, M. J. PEREIRA ${ }^{4}$, \\ A. SOARES $^{4}$ and F. CATARINO ${ }^{1}$ \\ ${ }^{1}$ MLJB-Museu, Laboratório e Jardim Botânico, Rua da Escola Politécnica, no. 58, \\ 1250-102 Lisboa, Portugal, e-mail: s.augusto@fc.ul.pt \\ ${ }^{2}$ CEBV-Centro de Ecologia e Biologia Vegetal,Campo Grande, Edifício C2, $4^{\circ}$ Piso, \\ 1749-016 Lisboa, Portugal \\ ${ }^{3}$ CEBV-Campo Grande, Bloco C2, Piso 4, 1749-016 Lisboa, Portugal; Universidade Atlântica, \\ Fábrica da Pólvora, 2745-615 Barcarena, Portugal \\ ${ }^{4}$ CMRP-Centro de Modelização de Reservatórios Petrolíferos, Instituto Superior Técnico, \\ Av. Rovisco Pais, 1049-001 Lisboa, Portugal
}

(Received: 23 April 2004; accepted: 5 May 2004)

\begin{abstract}
Polychlorodibenzeno-dioxins and polychlorodibenzeno-furans (PCDD/Fs) are considered among the most toxic compounds on earth. The aim of the present study was to evaluate atmospheric $\mathrm{PCDD} / \mathrm{F}$ deposition and identify the areas with greater deposition of these compounds in an important industrialized and urbanized region of Portugal, using lichens as biomonitors. For this purpose, samples of the lichen Xanthoria parietina were collected at 60 sampling sites, covering urban, industrial, forestry and agriculture areas, and analyzed for PCDD/Fs, sulfur, nitrogen, zinc, iron, chromium, lead, cobalt, nickel, copper, calcium, manganese, magnesium and potassium. The concentrations of $\mathrm{PCDD} / \mathrm{Fs}$ in lichens were compared with the other elements and related to land-use and population density. The results obtained through the geostatistical interpolations and after principal component analysis have shown that PCDD/F deposition estimated by lichens is greater near industrial and highly populated urban areas. We found that lichens are suitable biomonitors of PCDD/F atmospheric deposition and can contribute to a better knowledge of air quality in a region, enabling identification of critical pollutant deposition areas.
\end{abstract}

Key words: dioxins, furans, geostatistic, land use, lichens, biomonitors, atmospheric pollution

\section{Introduction}

People are exposed to a wide spectrum of atmospheric pollutants, which are a threat to human health. Because most of these substances occur in very low concentrations that vary considerably in space and time, they are difficult to measure. The use of biomonitors to perform these measurements has advantages, since certain types of biological organisms become enriched in the pollutants to be measured. Thus, biomonitors can provide a measured of integrated exposure over a given time, so that analytical limitations and measurement uncertainty are reduced. Moreover, as 
they enable a high spatial density of sampling points, biomonitors ensure spatial representativeness of the measurements.

Lichens, consisting of a fungus and an alga or cyanobacterium, are biomonitors with a good accumulation capacity that allows the determination of pollutant deposition in terrestrial ecosystems. They have been extensively used to biomonitor a variety of elements, such as sulfur, nitrogen, fluoride, metals, radionuclides, and various organic compounds like PCBs (polychlorinated biphenyls), PAHs (Polycyclic Aromatic Hydrocarbons), and substances from organochloride pesticides (HCHs and HCB) (Villeneuve et al., 1988; Herzig, 1989; Calamari et al., 1991; Garty, 2000; Owczarek et al., 2001; Guidotti et al., 2003). This well-established technique has been widely used in European countries to evaluate atmospheric deposition status since the late 1960s.

A specific group of organic compounds, PCDD/Fs (polychlorinated dibenzodioxins or dioxins and polychlorinated dibenzofurans or furans), have been of concern, as they are considered among the most toxic compounds on earth (Davy, 2004). Because of their chemistry, PCDD/Fs are both toxic and persistent in the environment. Although other similar organic compounds, like PCBs, were manufactured up to the 1970s, PCDD/Fs were never intentionally manufactured except for research and for standards, being adventitious byproducts of combustion, both industrial and natural (Davy, 2004). Major sources of dioxins have been related to industrial activities that include combustion processes and more recently to mobile sources, such as vehicle traffic (Chang et al., 2004). Little attention has been given to nonindustrial emission sources, so that reduction strategies have only been applied to the industrial sector, with urban sources, which are more difficult to control, being underestimated (Qua $\beta$ et al., 2004).

The European Union has recommended the development of indicators to monitor the impact of regulatory controls on future levels of human exposure to $\mathrm{PCDD} / \mathrm{Fs}$, particularly concentrations in air and deposition (Buckley-Golder, 1999). Concentrations in air and measures of deposition in biomonitors have been considered more responsive to emission reductions (Buckley-Golder, 1999).

Although there are a few publications concerning the use of lichens as biomonitors of organic compounds, such as PAHs and PCBs (Villeneuve et al., 1988; Herzig, 1989; Garty, 2000; Owczarek et al., 2001; Guidotti et al., 2003), to our knowledge this is the first regional case-study to use lichens as biomonitors of PCDD/Fs. Thus we hypothesize that, as in previously studies concerning lichens as biomonitors of organic compounds, it will be shown that lichens are suitable biomonitors for estimating atmospheric PCDD/F deposition. Besides PCDD/Fs, we also measured several metals ( $\mathrm{Zn}, \mathrm{Fe}, \mathrm{Mg}, \mathrm{Mn}, \mathrm{Ca}, \mathrm{K}, \mathrm{Cu}, \mathrm{Pb}, \mathrm{Co}, \mathrm{Cr}$ and $\mathrm{Ni}$ ), sulfur and nitrogen, relative to the land use in a region that is simultaneously important in terms of industry, urbanization and population density. Our aim was to relate PCDD/Fs measured in lichens to both land use and to other pollutants deposited in the region. Our hypothesis is that PCDD/F deposition occurs mainly in industrial and urban areas. 


\section{Materials and Methods}

\subsection{SAMPLING}

We selected Setúbal peninsula, located in the south of Portugal, for this study because it is one of the most industrialized and densely populated areas of the country, covering an area of 150,000 ha (Figures 1 and 2). Among the industries present in the region, we can spotlight iron and steel plants, cement mills, power plants, several chemical plants and hospital incinerators. At the same time, this region is rich in natural areas, notably Mediterrean woodlands, salt-marshes, and rocky and sand beaches, some of them with preserved sand dunes (Figure 2). In order to test the influence of the land-use in PCDD/F and other elements deposition,

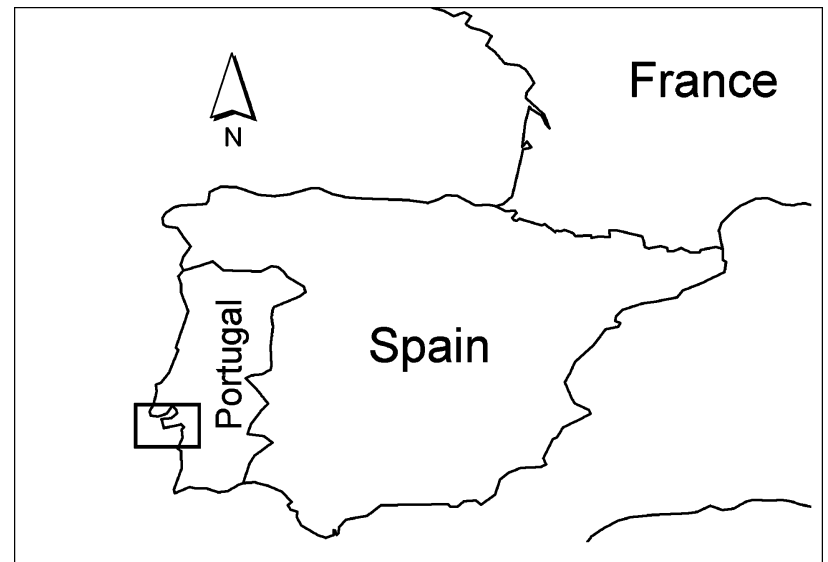

Figure 1. Location of the study area, Setúbal peninsula (marked with a square), in Portugal and Europe.

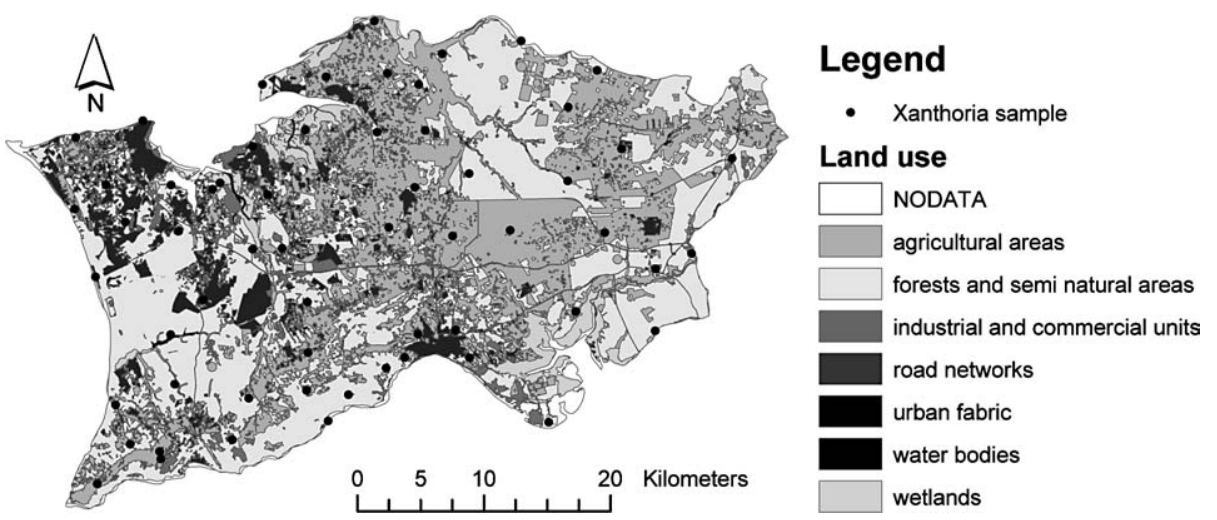

Figure 2. Land use map of the study area, Setúbal peninsula (developed by the Life Environment Program ENV/P/000556 and Life Nature Program 98-NAT/P/5235), with the distribution of the 60 sampling sites where the lichen Xanthoria parietina was collected from house rooftiles (represented by dark points). 
lichens were sampled at 60 sites, covering urban, industrial, agriculture, forest and road areas (Figure 2) in a sampling grid of 4 to $4 \mathrm{~km}$.

In order to select the lichen species and the substrate to sample the biomonitor in the chosen region, a preliminary survey of the foliose and fruticose lichen species and respective substrates present was performed (data not shown). We found that it was not possible to have the same tree to sample epiphytic lichens all over the region in the selected grid. In most of urban and industrial areas the fruticose lichens were absent and the only foliose lichen present was Xanthoria parietina (L.) Th. Fr. Thus we selected the tolerant lichen species X. parietina (Gaio-Oliveira et al., 1999; Silberstein et al., 1996a, b; Sarret et al., 1998), collected from house rooftiles. Due to the high spread of houses in this area it was possible to find a roof with $X$. parietina in every plot. The sampling was performed during March 2000, after a dry period of 84 days (precipitation below $7 \mathrm{~mm}$ ).

After collection, the lichens were stored in plastic bags and transported to the laboratory, where the unwashed samples were immediately dried at room temperature and sorted to remove extraneous material. Special care was taken when sorting in order to select only the chosen species $X$. parietina, thus avoiding possible errors due to the presence of other lichen species, such as Xanthoria calcicola Oksner. The cleaned samples were then ground (Glen Creston Ltd. MM 2000) and separated into three parts: one for metal analysis, another for sulfur and nitrogen, and the third for dioxins and furans (PCDD/Fs).

\subsection{SAMPLE ANALYSIS}

For metal analysis, ground lichen samples of approximately $100 \mathrm{mg}$ dry weight (lichens dried at $50^{\circ} \mathrm{C}$ for $24 \mathrm{~h}$ in a hot air oven) were digested with $3 \mathrm{ml}$ of nitric acid $(65 \%)$ at $120^{\circ} \mathrm{C}$. Glass tubes with $3 \mathrm{ml}$ of nitric acid and without lichens were used as controls. Zinc, Fe, Mg, Mn, Ca and $\mathrm{K}$ were analyzed by atomic absorption spectrophotometry (SpectrAA/50 Varian), using an air/acetylene mixture flame. Before $\mathrm{Ca}$ and $\mathrm{K}$ analysis, $\mathrm{CsCl}$ and $\mathrm{LaCl}_{3}(1 \mathrm{~g} / \mathrm{l})$ were added to the samples to prevent ionization and the formation of refractory compounds. Lead, $\mathrm{Ni}, \mathrm{Cr}, \mathrm{Co}$ and $\mathrm{Cu}$ were analyzed by atomic absorption spectrophotometry (GBC 932 plus) using a graphite furnace (GBC GF 3000). The analytical accuracy of the results was checked against the reference material IAEA-336 (Stone et al., 1995). The results of the analyzed elements were within the confidence intervals of the certified values. The precision of analyses was $6.6 \mu \mathrm{g} / \mathrm{g}$ for $\mathrm{Zn}, 19.2 \mu \mathrm{g} / \mathrm{g}$ for Fe, $24.9 \mu \mathrm{g} / \mathrm{g}$ for $\mathrm{Mg}$, $2.2 \mu \mathrm{g} / \mathrm{g}$ for Mn, $60.6 \mu \mathrm{g} / \mathrm{g}$ for Ca, $35.1 \mu \mathrm{g} / \mathrm{g}$ for K, $1.9 \mu \mathrm{g} / \mathrm{g}$ for Cu, $0.7 \mu \mathrm{g} / \mathrm{g}$ for $\mathrm{Pb}, 0.1 \mu \mathrm{g} / \mathrm{g}$ for $\mathrm{Co}, 1.3 \mu \mathrm{g} / \mathrm{g}$ for $\mathrm{Cr}$ and $1.8 \mu \mathrm{g} / \mathrm{g}$ for $\mathrm{Ni}$.

For total sulfur $(\mathrm{S})$ and total nitrogen $(\mathrm{N})$ analysis, ground lichen samples were dried at $50^{\circ} \mathrm{C}$ for $24 \mathrm{~h}$. Three replicates of each sample were separated (2.5 $\mathrm{mg}$ for $\mathrm{S}$ analysis and $1 \mathrm{mg}$ for $\mathrm{N}$ analysis) in a high performance balance (Sartorius Microanalytical Balance) and analyzed by elemental mass analysis (Euro Vector CHNS-O Elemental Analyser). The standards used were atropin 
$\left(\mathrm{C}_{17} \mathrm{H}_{23} \mathrm{NO}_{3}\right.$ with $\left.4.84 \% \mathrm{~N}\right)$ for nitrogen analysis and $\mathrm{BBOT}\left(\mathrm{C}_{26} \mathrm{H}_{26} \mathrm{~N}_{2} \mathrm{O}_{2} \mathrm{~S}\right.$ with $7.44 \% \mathrm{~S}$ ) for sulfur analysis. The precision of analysis was $0.03 \%$ for $\mathrm{S}$ and $0.07 \%$ for $\mathrm{N}$, and the accuracy was $0.02 \%$ for $\mathrm{S}$ and $0.01 \%$ for $\mathrm{N}$.

For PCDD/Fs, ground and dried samples were added to labeled standards ${ }^{13} \mathrm{C}_{12}$, subjected to toluene extraction and purified to remove intrusive substances. $\mathrm{PCDD} / \mathrm{Fs}$ were quantified by gas chromatography and high-resolution mass spectrometry (Fisons Autospec Ultima System). The precision and accuracy of the analysis was checked against reference material. These organic trace analyses took place in the specialized analytical laboratory TERRA PROTECTA.

\subsection{DATA ANALYSIS}

For calculation of the land use with impact at each sampling point a circular buffer was drawn with a radius of $2 \mathrm{~km}$ around each sampling site and the percentage of the area occupied by each land use was calculated. For this we considered land use to be divided into forestry (FOR), agriculture (AGR), industrial (IND), urban (URB) and road (ROAD) areas. The population density (P DEN) of each sampling point was taken as that used by the local parish published by the national statistics authority (INE, 2004).

Pearson linear correlations between the chemical elements concentrations, land use classes and population density were calculated. Based on these bivariate linear correlations and analysis of the biplots, relevant chemical elements in lichens, land use classes and the population density were selected to perform a principal component analysis (PCA). Due to the large number of variables (22) against the number of samples (60), reduction in the number of variables to perform the PCA was advisable. The PCA was performed using the program STATISTICA 5.0 for Windows (Statistical StatSoft, Inc., 1995). The PCDD/F, and $\mathrm{Cu}$ and $\mathrm{Pb}$ concentrations in lichens in the study area were interpolated for the entire area by using ordinary kriging (geostatistical estimator) based on the variogram models fitted for each element.

\section{Results and Discussion}

The concentration values for the elements measured in the lichen $X$. parietina are displayed in Table I and were compared with other studies using the same lichen species. In general, for metals, sulfur and nitrogen, the levels in our work are of the same order of magnitude as those obtained in other studies (Gaio-Oliveira et al., 1999, 2001; Scerbo et al., 2002; Cicek and Koparal, 2003). Due to the fact that we could not find any scientific study concerning measures of PCDD/Fs in lichens, we compared the concentrations found in this study with concentrations found in other matrices. The values obtained in our samples were much higher than those found for fruits and vegetables in other studies (Lovett et al., 1997; Coutinho et al., 1999) and the range of PCDD/F concentrations in lichens seemed to be closer to that found in soil samples (sinks for these compounds), presenting values greater than those 
Table I. Mean, standard deviation, minimum and maximum concentrations (displayed in $\mu \mathrm{g} \mathrm{g}^{-1}$ for metals, sulfur and nitrogen, and in $\mathrm{n} \mathrm{Kg}^{-1}$ for PCDD/Fs) of elements measured through chemical analysis in the lichen Xanthoria parietina collected in March 2000 in the Setúbal peninsula; $n=60$

\begin{tabular}{|c|c|c|c|c|}
\hline \multirow[b]{2}{*}{ Elements } & \multicolumn{4}{|c|}{ Statistical resume } \\
\hline & Mean & $\begin{array}{l}\text { Standard } \\
\text { deviation }\end{array}$ & Minimum & Maximum \\
\hline $\mathrm{PCDD} / \mathrm{F}$ & 427.74 & 307.54 & 73.70 & 1913.30 \\
\hline S & 3920.43 & 594.93 & 2546.67 & 5583.33 \\
\hline $\mathrm{N}$ & 26712.83 & 5044.55 & 18410.00 & 46390.00 \\
\hline $\mathrm{Zn}$ & 132.58 & 144.19 & 23.83 & 1045.14 \\
\hline $\mathrm{Fe}$ & 2739.54 & 1588.72 & 427.61 & 8358.39 \\
\hline $\mathrm{Mg}$ & 1044.89 & 495.50 & 558.92 & 4318.14 \\
\hline $\mathrm{Mn}$ & 50.96 & 28.94 & 22.22 & 174.15 \\
\hline $\mathrm{Ca}$ & 2210.83 & 1960.10 & 609.54 & 10490.86 \\
\hline K & 3973.08 & 1348.09 & 1358.13 & 6970.41 \\
\hline $\mathrm{Cu}$ & 34.90 & 34.39 & 6.88 & 213.19 \\
\hline $\mathrm{Pb}$ & 7.73 & 5.78 & 0.83 & 29.82 \\
\hline Co & 3.22 & 1.66 & 1.14 & 7.44 \\
\hline $\mathrm{Cr}$ & 107.09 & 90.13 & 2.82 & 345.99 \\
\hline $\mathrm{Ni}$ & 12.64 & 10.04 & 2.37 & 47.31 \\
\hline
\end{tabular}

Table II. Pearson correlation between PCDD/Fs and other elements measured in the lichen Xanthoria parietina collected in the Setúbal peninsula; significant correlations $(p<0.01)$ are shadowed $(n=60)$

\begin{tabular}{llllllllllllll}
\hline Elements & $\mathrm{S}$ & $\mathrm{N}$ & $\mathrm{Zn}$ & $\mathrm{Fe}$ & $\mathrm{Mg}$ & $\mathrm{Mn}$ & $\mathrm{Ca}$ & $\mathrm{K}$ & $\mathrm{Cu}$ & $\mathrm{Pb}$ & $\mathrm{Co}$ & $\mathrm{Cr}$ & $\mathrm{Ni}$ \\
\hline PCDD/F & 0.170 & 0.087 & 0.288 & 0.174 & -0.052 & 0.018 & 0.013 & 0.211 & $\mathbf{0 . 5 9 3}$ & 0.200 & -0.009 & $\mathbf{0 . 4 4 3}$ & -0.119
\end{tabular}

detected in eggs and animals (Coutinho et al., 1999). One possible explanation may be related to the longevity of lichens; compared to plants, lichens intercept pollutants for longer periods. From a toxicological perspective, this feature allows an integrative image of atmospheric deposition.

Bivariate linear correlation analysis was used to evaluate the relationship between PCDD/Fs and the other elements. The correlation table (Table II) shows that only $\mathrm{Cu}$ and $\mathrm{Cr}$ have significant $(p<0.01)$ correlations with PCDD/Fs. Correlation analysis was also performed in order to assess the relationship between land use and the elements analyzed in lichens (Table III). The results showed that in general all bivariate linear correlations are low. The significant $(p<0.01)$ positive correlations were observed between population density and $\mathrm{Pb}, \mathrm{Cu}$ and $\mathrm{PCDD} / \mathrm{Fs}$, between urban areas and $\mathrm{Pb}$ and $\mathrm{Cu}$, and between roads and $\mathrm{Cu}$ and $\mathrm{Zn}$ and $\mathrm{Ni}$ (Table III). Agricultural areas were negatively correlated with $\mathrm{Mg}$ and forestry areas negatively correlated with sulfur and nitrogen. 
Table III. Pearson correlation between the pollutants measured in the lichen Xanthoria parietina collected on the Setúbal peninsula, and land-use and population density $2 \mathrm{~km}$ around the sampling sites; significant correlations $(p<0.01)$ are shadowed $(n=60)$

\begin{tabular}{|c|c|c|c|c|c|c|}
\hline \multirow[b]{2}{*}{ Elements } & \multicolumn{6}{|c|}{ Land-use and population density $2 \mathrm{~km}$ around the lichen sampling points } \\
\hline & AGR & FOR & IND & ROAD & URB & P. DEN \\
\hline $\mathrm{PCDD} / \mathrm{F}$ & -0.196 & 0.221 & 0.260 & 0.280 & 0.345 & 0.384 \\
\hline S & 0.232 & $-\mathbf{0 . 4 8 3}$ & 0.210 & 0.032 & 0.056 & 0.141 \\
\hline $\mathrm{N}$ & 0.342 & -0.410 & 0.101 & -0.046 & 0.004 & -0.153 \\
\hline $\mathrm{Zn}$ & -0.270 & -0.003 & 0.334 & 0.508 & 0.162 & 0.275 \\
\hline $\mathrm{Fe}$ & -0.250 & -0.162 & 0.060 & 0.215 & 0.063 & 0.329 \\
\hline $\mathrm{Mg}$ & -0.426 & 0.070 & -0.030 & 0.036 & 0.185 & 0.140 \\
\hline $\mathrm{Mn}$ & -0.296 & 0.083 & 0.005 & 0.236 & 0.036 & -0.065 \\
\hline $\mathrm{Ca}$ & -0.236 & 0.141 & 0.250 & -0.047 & 0.184 & 0.035 \\
\hline K & 0.001 & -0.324 & 0.071 & 0.101 & 0.228 & 0.151 \\
\hline $\mathrm{Cu}$ & -0.241 & -0.288 & 0.288 & 0.357 & 0.382 & 0.682 \\
\hline $\mathrm{Pb}$ & -0.252 & -0.303 & 0.214 & 0.030 & 0.360 & 0.608 \\
\hline Co & -0.219 & 0.005 & -0.119 & 0.159 & 0.098 & 0.167 \\
\hline $\mathrm{Cr}$ & -0.152 & -0.001 & -0.018 & 0.311 & 0.196 & 0.182 \\
\hline $\mathrm{Ni}$ & -0.204 & 0.101 & -0.086 & 0.431 & -0.122 & -0.046 \\
\hline
\end{tabular}

A principal component analysis(PCA) of the concentration of selected elements at each sampling site and the proportion of each land use related to the same sampling site was carried out (Figures 3 and 4). The PCA extracted three factors providing a multidimensional model that accounted for $64.3 \%$ of the variance. The first factor (which explained $32.2 \%$ of the variance) associates PCDD/Fs, $\mathrm{Cu}, \mathrm{Pb}$, industrial areas, population density and urban areas in opposition to agriculture and forestry areas (Figures 3 and 4). The second factor (explaining 20.8\% of the variance) associates nitrogen and sulfur in opposition to forestry land use areas (Figure 3). The third factor (explaining $11.3 \%$ of the variance) associates road areas with Zn (Figure 4).

The maps in Figures 5, 6 and 7, show geostatistical interpolations for concentrations of $\mathrm{PCDD} / \mathrm{Fs}, \mathrm{Cu}$ and $\mathrm{Pb}$, measured in lichens in Setúbal peninsula. It was found that the concentrations of $\mathrm{PCDD} / \mathrm{Fs}, \mathrm{Cu}$ and $\mathrm{Pb}$ in lichens have spatial gradients related to urban and industrial areas. However, the spatial pattern of PCDD/Fs has a larger spatial continuity, with a two-structure variogram with 6 and $26 \mathrm{~km}$ ranges, than $\mathrm{Cu}$ and $\mathrm{Pb}$, which have only a 10 and $9 \mathrm{~km}$ range, respectively. This is possibly explained by the fact that particles rich in $\mathrm{Cu}$ and $\mathrm{Pb}$ are usually larger and heavier than PCDD/Fs, and consequently tend to deposit closer to the source. Some authors cite that less than $10 \%$ of the PCDD/F deposition occurs locally, whereas long range transport are up to $100 \mathrm{~km}$ distance from the source (Lohman and Seigneur, 2001). 


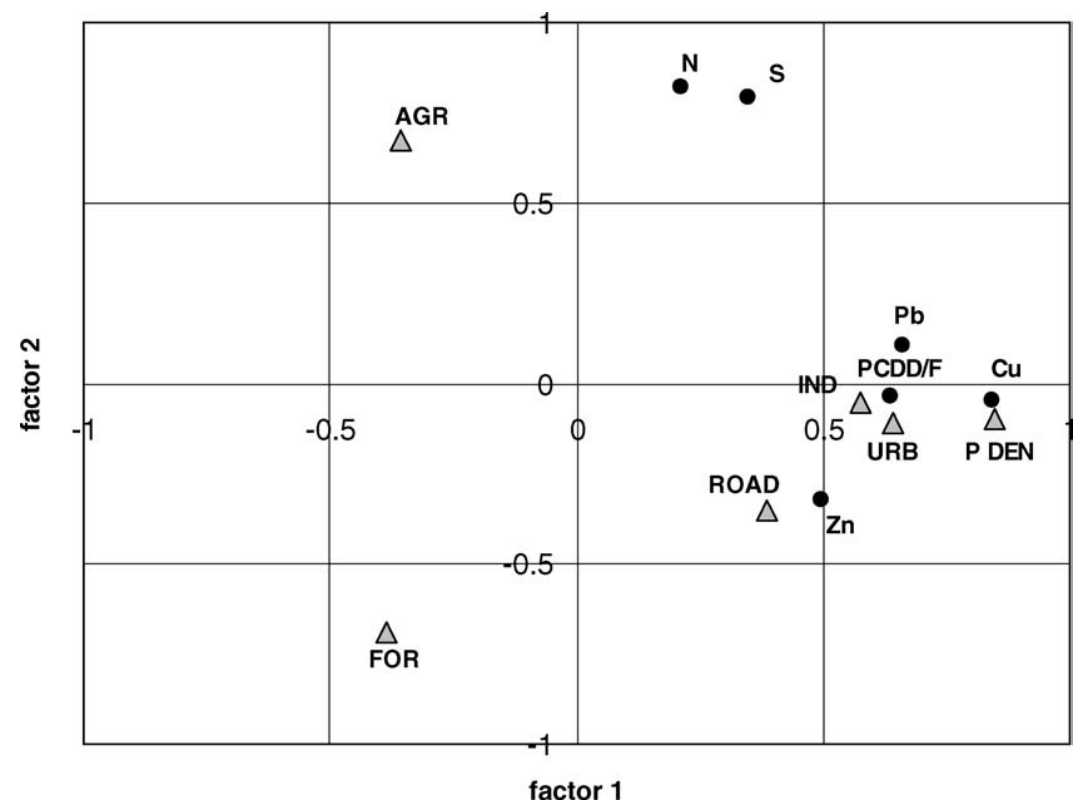

Figure 3. Principal component analysis (PCA) of the pollutant data obtained through chemical analysis of the 60 samples of the lichen Xanthoria parietina collected in March 2000 in the Setúbal peninsula; the first two factors explain $53.0 \%$ of the data variance.

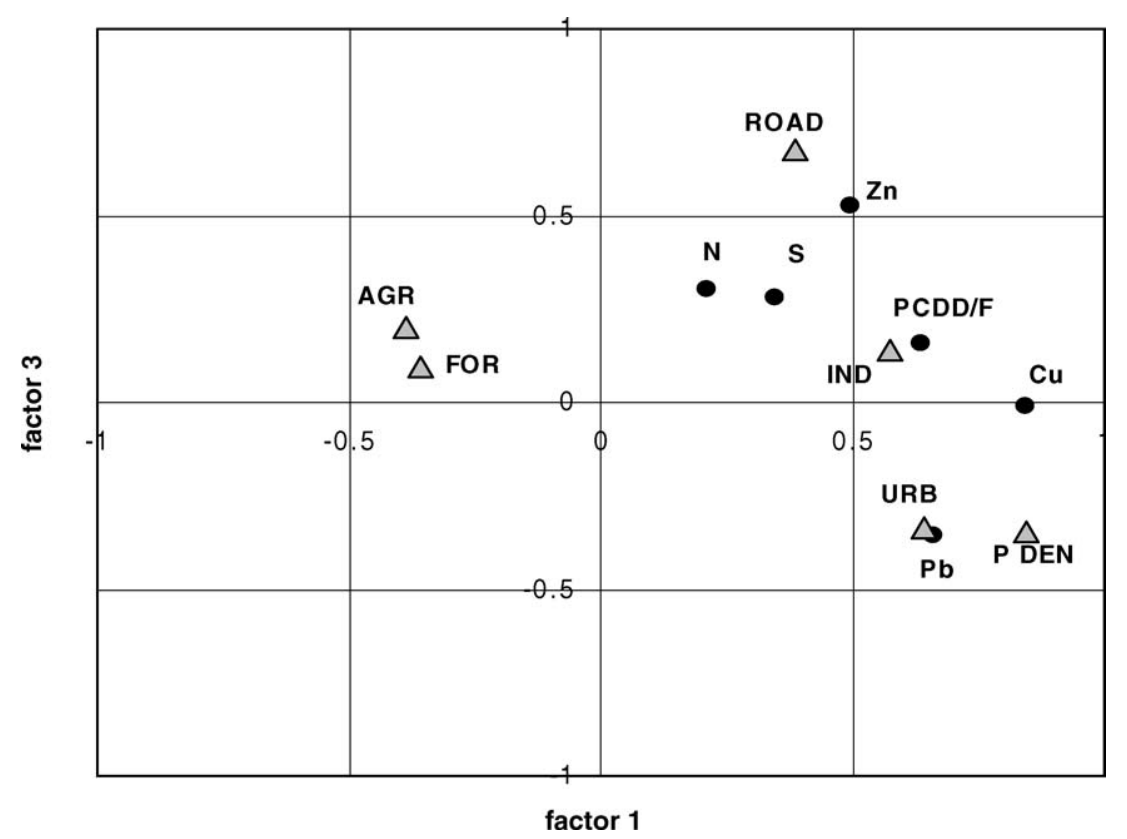

Figure 4. Principal component analysis (PCA) of the pollutant data obtained through chemical analysis of the 60 samples of the lichen Xanthoria parietina collected in March 2000 in the Setúbal peninsula; the first and third factors explain $43.5 \%$ of the data variance. 

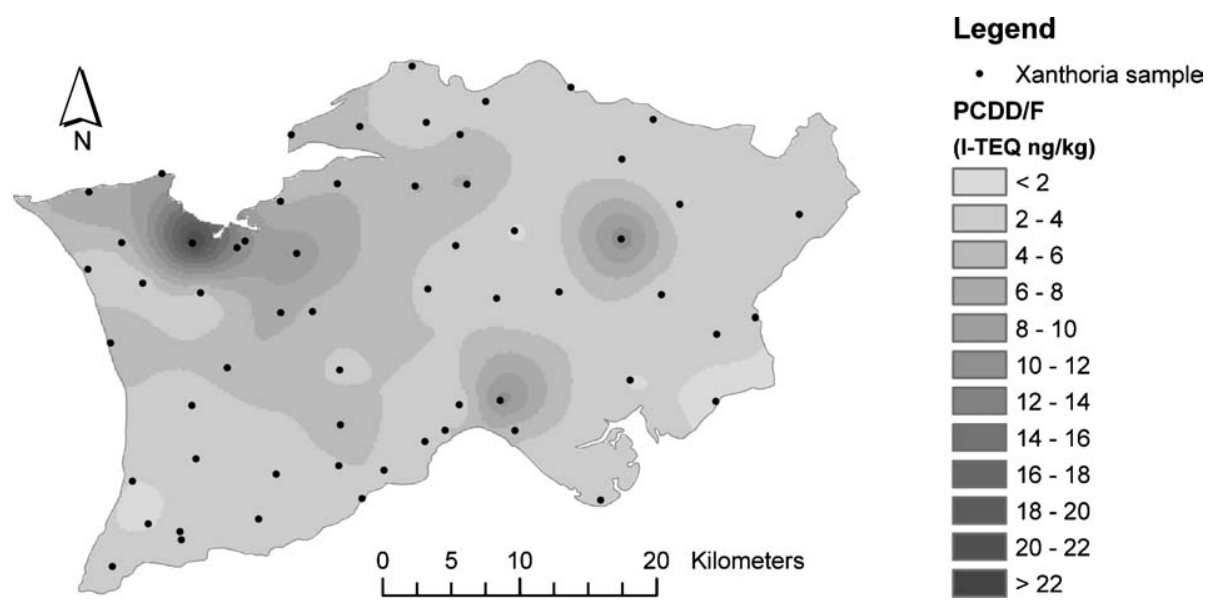

Figure 5. Spatial distribution of PCDD/F concentrations $\left(\mathrm{ng} \mathrm{Kg}^{-1}\right)$ obtained through chemical analysis of lichen samples collected in March 2000 in the Setúbal peninsula, Portugal. Concentrations increase gradually from light to dark colours.
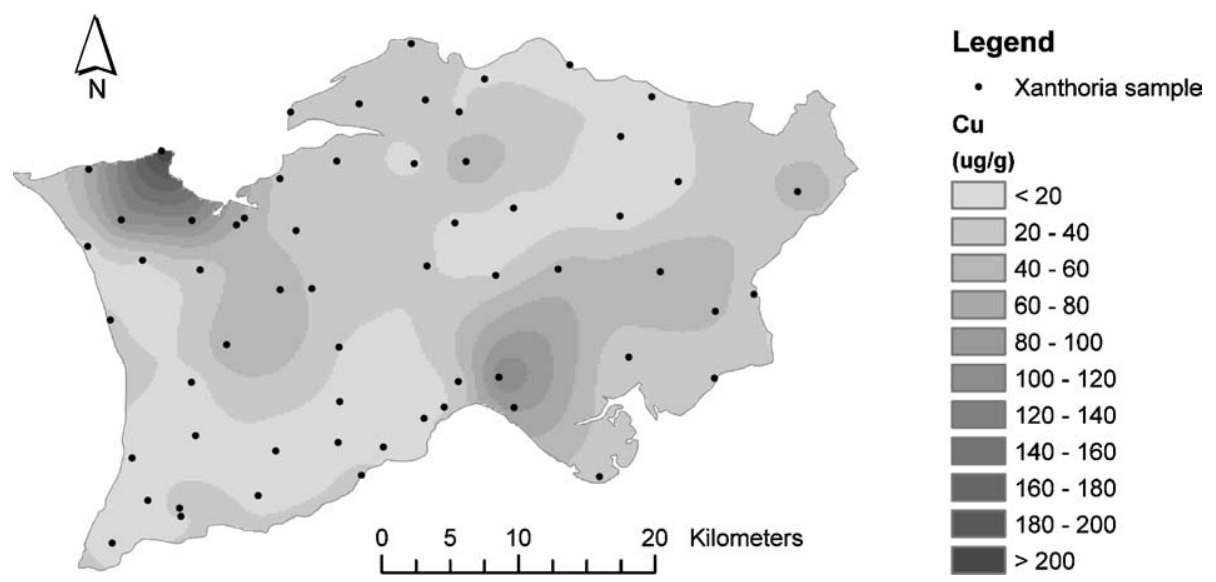

Figure 6. Spatial distribution of concentrations of $\mathrm{Cu}\left(\mu \mathrm{gg}^{-1}\right)$ obtained through chemical analysis of lichen samples collected in March 2000 in the Setúbal peninsula, Portugal. Concentrations increase gradually from light to dark colours.

Supporting the results obtained through the geostatistical interpolations, and confirming our initial hypothesis, the PCA results have shown that PCDD/F deposition estimated by lichens is greater near industrial and highly populated urban areas (Figures 3 and 4). Sustaining our data, several industries located in the studied region have processes that lead to the production and release of PCDD/Fs, such as iron and steel plants, cement mills, power plants, several chemical plants and hospital incinerators, (Coutinho et al., 1998; Alcock et al., 2001; Buekens et al., 2001; Ogura et al., 2001; Anderson and Fischer, 2002; Davy, 2004; Qua $\beta$ et al., 2004). On the other hand, our study area, the Setúbal peninsula, has population densities that 

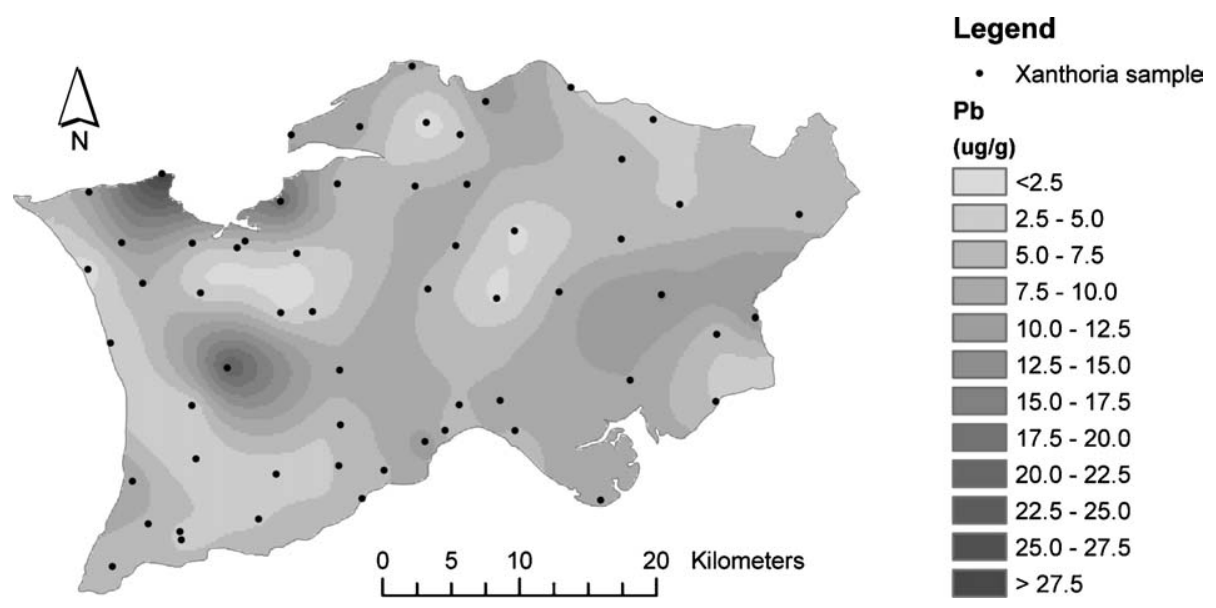

Figure 7. Spatial distribution of concentrations of $\mathrm{Pb}\left(\mu \mathrm{gg}^{-1}\right)$ obtained through chemical analysis of lichen samples collected in March 2000 in the Setúbal peninsula, Portugal. Concentrations increase gradually from light to dark colours.

vary from 99.4 to 2454.2 people $/ \mathrm{km}^{2}$, depending on the municipality (INE, 2004). This maximum value is twice as high as those reported for the largest municipalities of the country, Lisboa and Porto (both outside the study region). Several authors quote that vehicles exhaust are the source of PCDD/Fs in urban areas (Ballschmiter et al., 1986; Hagenmaier et al., 1990; Oehme et al., 1991; Wevers et al., 1992; Quaß et al., 2004; Chang et al., 2004). Supporting this, it was shown that PCDD/Fs were related to $\mathrm{Cu}$ and $\mathrm{Cr}$ measured in lichens, which are known to be vehicle emission indicators (Ormod, 1984; Saquid et al., 1989; Ward, 1989) (Table II).

The complex land use pattern, where industrial areas are within highly populated areas, makes it difficult to clearly separate the contribution of PCDD/F deposition to urban and industrial areas (Figures 2, 3 and 4). For instance, some of the industries present in the region, e.g. hospital waste incinerators, are located inside urban areas and their emissions might be added to the overall urban pollution detected by lichens. More investigation will be needed to track industry and urban emission/deposition patterns, through comparison between industrial and urban PCDD/F congeners emission profile and the ones detected in lichens.

Agriculture and forestry were the least contaminated land use classes, since they were always far from all the pollutants in the PCA analysis (Figures 3 and 4).

Supporting our initial hypothesis, we showed that lichens could be used as biomonitors for PCDD/Fs. This conclusion is supported by the fact that concentrations of PCDD/Fs in lichens have shown spatial gradients related to urban and industrial areas (Figure 5). Moreover, the concentrations found in these organisms are well above detection limits (Table I), meaning that they can be successfully used for monitor PCDD/F deposition without having detection limits constraints. Biomonitors, such as vegetation (Domingo et al., 2000, 2001, 2002; Schuhmacher et al., 2002), cows milk (Alcock et al., 2002; Schmid et al., 2003), and mosses 
(Umlauf et al., 1999), have been successfully applied to identify or monitor ambient air concentrations in the neighbourhood of potential point sources (BuckleyGolder, 1999). The outer waxy surfaces of pine needles, kale and grasses absorb atmospheric lipophilic pollutants and have therefore been used as monitoring systems for PCDD/Fs. However, the advantage of using lichens compared to pine needles or other higher plant is that lichens do not have the complication of the pollutants being taken up by the roots, since the soils are sinks for these pollutants. Nevertheless, in order to use lichens as PCDD/F biomonitors more work will be needed to establish the suitability of other lichen species as PCDD/F biomonitors, the temporal variability of these pollutants in lichens, and the ability to track sources through their congeners and homologue analysis.

\section{Conclusions}

Supporting our initial hypothesis, we showed that PCDD/F deposition occurs mainly in industrial and highly populated urban areas. The complex land use pattern, where industrial areas are within highly populated areas, makes it difficult to clearly separate the contribution of PCDD/F deposition to urban and industrial areas. More investigation will be needed to track industry and urban emission/deposition patterns, through comparison between industrial and urban PCDD/F congeners emission profile and the ones detected in lichens.

Our results showed that lichens are suitable biomonitors of PCDD/Fs atmospheric deposition and can contribute to a better knowledge of air quality in a region, enabling: (i) identification of critical pollutant deposition areas, (ii) optimization of pollutant monitoring networks, (iii) production of risk assessment studies, including epidemiological research, and (iv) help in the decision-making process.

\section{Acknowledgments}

The authors are grateful for the financial support from Life Environment programs $\mathrm{ENV} / \mathrm{P} / 000830$ and $\mathrm{ENV} / \mathrm{P} / 000556$.

\section{References}

Alcock, R. E., Sweetman, A. J., Anderson, D. R., Fischer, R., Jennings, R. A., and Jones, K. C., 2002: Using PCDD/F congener patterns to determine the source of elevated TEQ concentrations in cows milk: A case study, Chemosphere 46, 383-391.

Alcock, R. E., Sweetman, A. J. and Jones, K. C., 2001: A congener-specific PCDD/F emissions inventory for the UK: Do current estimates account for the measured atmospheric burden? Chemosphere 43, 183-194.

Anderson, D. R. and Fischer, 2002: Sources of dioxins in United Kingdom. The steel industry and other sources, Chemosphere 46, 371-381.

Ballschmiter, K., Buchert, H., Niemezyk, R., Munder, A., and Swerev, M., 1986: Automobile exhausts vs. Municipal waste incineration as sources of polychloro-dibenzodioxins (PCDD) and furans (PCDF) found in the environment, Chemosphere 15, 901-915. 
Buckley-Golder, D., 1999: Compilation of EU dioxin exposure and health data, Task 1, AEA Technology, Oxfordshire, pp. 12-13.

Buekens, A., Stieglitz, L., Hell, K., Huang, H., and Segers, P., 2001: Dioxins from thermal and metallurgical processes: Recent studies for the iron and steel industry, Chemosphere 42, 729-735.

Calamari, D., Bacci, E., Focardi, S., Gaggi, C., Morosini, M., and Vighi, M., 1991: Role of plant biomass in the global environmental portioning of chlorinated hydrocarbons, Environ. Sci. Technol. 25, 1489-1495.

Chang, M. B., Chang, S. H., Chen, Y. W., and Hsu, H. C., 2004: Dioxin emission factors for automobiles from tunnel air sampling in Northern Taiwan, Sci. Total Environ. 325, 129-138.

Cicek, A. and Koparal, A. S., 2003: The assessment of air quality and identification of the pollutant sources in the Eskisehir region Turkey using Xanthoria parietina (L.) Th. Fr. (1860), Fresen. Environ. Bull. 12(1), 24-28.

Coutinho, M., Boia, C., Borrego, C., Mata, P., Costa, J., Rodrigues, R., Gomes, P., and Neves, M., 1999: Environmental baseline levels of dioxins and furans in the region of Oporto, Organohalogen Compd. 43, 131-136.

Coutinho, M., Conceição, M., Borrego, C., and Nunes, M., 1998: Atmospheric impact assessment and monitoring of dioxin emissions of municipal solid waste incinerators in Portugal, Chemosphere 37, 2119-2126.

Davy, C. W., 2004: Legislation with respect to dioxins in the workplace, Environ. Int. 30, 219-233.

Domingo, J. L., Granero, S., and Schuhmacher, M., 2001: Congener profiles of PCDD/Fs in soil and vegetation samples collected near to a municipal waste incinerator, Chemosphere 43, 517-524.

Domingo, J. L., Schuhmacher, M., Agramunt, M. C., Llobet, J. M., Rivera, J., and Müller, L., 2002: $\mathrm{PCDD} / \mathrm{F}$ levels in the neighbourhood of a municipal solid waste incinerator after introduction of technical improvements in the facility, Environ. Int. 28, 19-27.

Domingo, J. L., Schuhmacher, M., Müller, L., Rivera, J., Granero, S., and Llobet, J. M., 2000: Evaluating the environmental impact of an old municipal waste incinerator: PCDD/F levels in soil and vegetation samples, J. Hazard. Mater. 76, 1-12.

Gaio-Oliveira, G., Branquinho, C., Máguas, C., and Correia, O., 1999: Spatial impact of atmospheric dust from a cement mill in Serra da Arrábida using lichens as biomonitors, Revista de Biologia 17, 33-42.

Gaio-Oliveira, G., Branquinho, C., Máguas, C., and Martins-Loução, M. A., 2001: The concentration of nitrogen in nitrophilous and non-nitrophilous lichen species, Symbiosis 31, 187-199.

Garty, J., 2000: Environment and elemental content in lichens, in B. Markert and K. Friese (eds.), Trace Elements - Their Distribution and Effects in the Environment, Elsevier Science, Amsterdam, pp. 245-276.

Guidotti, M., Stella, D., Owczarek, M., De Marco, A., and De Simone, C., 2003: Lichens as polycyclic aromatic hydrocarbon bioaccumulators used in atmospheric pollution studies, $J$. Chromatogr. A 385, 185-190.

Hagenmaier, H., Dawidowsky, N., Weberru, B. U., Hutzinger, O., Schwind, K. H., and Thomas, H., 1990: Emission of polychlorinated dibenzodioxins and dibenzofurans from combustion engines, Organohalogen Compd. 2, 329-334.

Herzig, R., 1989: Multi-residue analysis with passive biomonitoring: A new approach for volatile multi-elements, heavy metals and polycyclic aromatic hydrocarbons with lichens in Switzerland and the Principality of Liechtenstein, in B. Markert (ed.), Plants as Biomonitors, Indicators for Heavy Metals in the Terrestrial Environment, Weinheim, pp. 285-328.

INE, 2004: Instituto Nacional de Estatística, Portugal (www.ine.pt).

Lohman, K. and Seigneur, C., 2001: Atmospheric fate and transport of dioxins: Local impacts, Chemosphere 45, 161-171.

Lovett, A. A., Foxall, C. D., and Chewe, D., 1997: PCB and PCDD/F congeners in locally grown fruit and vegetable samples in Wales and England, Chemosphere 34, 1421-1436. 
Oehme, M., Larssen, S., and Brevik, E. M., 1991: Emission factors of PCDD/CDF for road vehicles obtained by a tunnel experiment, Chemosphere 23, 1699-1708.

Ogura, I., Masunaga, S., and Nakanishi, J., 2001: Atmospheric deposition of polychlorinated dibenzo-p-dioxins, polychlorinated dibenzofurans, and dioxin-like polychlorinated biphenyls in the Kanto Region, Japan, Chemosphere 44, 1473-1487.

Ormrod, D. P., 1984: Impact of trace metal pollution on plants, in M. Treshow (ed.), Air Pollution and Plant Life, Wiley, New York, pp. 291-319.

Owczarek, M., Guidotti, M., Blasi, G., De Simone, C., De Marco, A., and Spadoni, M., 2001: Traffic pollution monitoring using lichens as bioaccumulators of heavy metals and policyclic aromatic hydrocarbons, Fresenius Environ. Bull. 10(1), 42-45.

Quaß, U., Fermann, M., and Bröker, G., 2004: The European dioxin air emission inventory project - Final results, Chemosphere 54, 1319-1327.

Saquid, M., Alam, I., El-Mubarek, A., and Al-Mohdar, H. M., 1989: Preliminary evaluation of mettal pollution from wear of auto tires, Bull. Environ. Contam. Toxicol. 42, 743-748.

Sarret, G., Manceau, A., Cuny, D., Haluwyn, C., Déruelle, S., Hazemann, J. L., Soldo, Y., EybertBérard, L., and Menthonnex, J. J., 1998: Mechanisms of lichen resistence to metallic pollution, Environ. Sci. Technol. 32, 3325-3330.

Scerbo, R., Ristori, T., Possenti, L., Lampugnani, L., Barale, R., and Barghigiani, C., 2002: Lichen ( Xanthoria parietina) biomonitoring of trace element contamination and air quality assessment in Pisa Province (Tuscany, Italy), Sci. Total Environ. 286, 27-40.

Schmid, P., Gujer, E., Zennegg, M., and Studer, C., 2003: Temporal and local trends of PCDD/F levels in cow's milk in Switzeland, Chemosphere 53, 129-136.

Schuhmacher, M., Bocio, A., Agramunt, M. C., Domingo, J. L., and Kok, H. A. M., 2002: PCDD/F and metal concentrations in soil and herbage samples collected in the vicinity of a cement plant, Chemosphere 48, 209-217.

Silberstein, L., Siegel, B. Z., Siegel, S. M., Mukhtar, A., and Galun, M., 1996a: Comparative studies on Xanthoria parietina, a pollution-resistent lichen, and Ramalina duriaei, a sensitive species. I. Effects of air pollution on physilogical processes, Lichenologist 28, 355-365.

Silberstein, L., Siegel, B. Z., Siegel, S. M., Mukhtar, A., and Galun, M., 1996b: Comparative studies on Xanthoria parietina, a pollution-resistent lichen, and Ramalina duriaei, a sensitive species. I. Evaluation of possible air pollution-protection mechanisms, Lichenologist 28, 367-383.

Statistical StatSoft , Inc., 1995: Version 5.1 for Windows.

Stone, S. F., Freitas, M. C., Parr, M. R., and Zeisler, R., 1995: Elemental characterization of a candidate lichen research material - IAEA 336, Fresen. J. Anal. Chem. 352, 277-281.

Umlauf, G., Mano, S., Hiller, B., Barbiere, M., and Facchetti, S., 1999: Recent dioxin levels in zone A of Seveso: Northern part of the Bosco delle Querce and the soil covering the landfills Collina di Meda and Collina di Seveso, Moni. Epidemio. Remediation, 155-166.

Villeneuve, J., Fogelqvist, E., and Cattini, C., 1988: Lichens as bioindicators for atmospheric pollution by chlorinated hydrocarbons, Chemosphere 17, 399-403.

Ward, N. I., 1989: Multielement contamination of British motorways environments, in J. P. Vernet (ed.), Heavy Metals in the Environment, Vol. 1, CEP Consultants, Edinburgh, pp. 174-176.

Wevers, M., De Fre, R., and Rymen, T., 1992: Dioxins and dibenzofurans in tunnel air, Organohalogen Compd. 9, 321-324. 